\title{
Measurement of Value at Risk (VaR) in Stock Invest- ment Using Monte Carlo Simulation Method
}

\author{
Dwi Handayani ${ }^{1 *}$, M. Nuha Alfan Thariq ${ }^{1}$ \\ ${ }^{I}$ Department of Industrial Engineering Faculty of Industrial Technology, Universitas Islam Indonesia, Yogyakarta, \\ Indonesia \\ *Corresponding author: $\underline{\text { dwihandayani@uii.ac.id }}$
}

\begin{abstract}
The finance industry, especially banking, is an industry that is often used by the public to make transactions. Banking is one of several business lines in the financial industry. Many industries in Indonesia are under pressure because of the Covid-19 pandemic, many cases have been confirmed by new policies stating that large social scale (PSBB). This policy affects many industries and one of them is banking. PT. East Java Regional Development Bank Tbk is one of the regional banks in Indonesia that provides credit to the community and small SME's (Small, and Medium Enterprises) in the regions, credit activity is very important for the banking industry because the activity generates cash flow. Stock investors investing in Bank Jatim will make decisions because of this pandemic to continue to generate returns in their investment portfolios. This study tries to measure the risk of investing in shares at PT. East Java Regional Development Bank Tbk for the past year using the Value at Risk method using Monte Carlo. The Value at Risk method is used to measure the maximum risk of loss in a company's stock performance. In the Monte Carlo method, random numbers are generated with a normal distribution, which is then carried out by calculating the Value on Risk using the results from random number generation. From the results of risk measurement using Value at Risk, the numbers are -5871809.812 at the $99 \%$ confidence level, -4183103.967 at the $95 \%$ confidence level, and 3195086.406 at the $90 \%$ confidence level where this can be seen that investors will experience a maximum loss of $6 \%$ with $99 \%$ confidence, $4 \%$ with $95 \%$ confidence, and $3 \%$ with confidence in the amount of $90 \%$ of the total initial investment fund in BJTM shares amounting to IDR 5,871,809,812, IDR 4,183,103,967, and IDR 3,195,086,406. From these results, this can be ignored that the level of confidence is directly proportional to the risk because the higher the level of trust used, the higher the probability of losses that can increase investors.
\end{abstract}

Keywords: VaR, Monte Carlo, Stock Investment

\section{INTRODUCTION}

Every human being in the world carries out economic activities to sustain life and get prosperity. Therefore, humans are competing to find something that they can use to carry out their lives. That something is called an economic tool. The very popular economic tool used today is money, and every human being has his way of getting money. Most people earn money by working, but some people get money from investing money/capital which is often referred to as investing. Investment is a commitment to a number of funds or other resources carried out at this time, to obtain several benefits in the future. An investor buys a number of shares today in the hope of obtaining a profit from an increase in stock prices or a certain amount of dividends (return on profits) in the future, as a reward for the time and risk associated with the investment [1].

Stocks are an investment alternative that is currently popular. The motivation of every investor to invest in shares is to get profit from capital gains (the difference between the selling and buying price) and also the annual dividend (profit sharing) that is routinely distributed to shareholders, as a reward for the time and risk associated with investing in shares. In an economy, almost all investments have risks or uncertainties in the future. Investors cannot know for sure the results that will be obtained from the investment that will be made. Investors will also face other things in investing. For 
example, if investors expect high returns, they should also be willing to bear high risks [2].

Risk is defined as unfulfilled loss or expectations. Risk can occur in any matter and field. In the financial sector, financial risk can be an adverse event and can affect the ability of an organization to achieve its objectives and implement planned strategies. The types of financial risk include risks of market, liquidity, and credit. Risks are often related to uncertainty factors, therefore this is necessary to take measures to mitigate the risks which are called risk management. The more an investor is reluctant to risk (risk-averse), the more investment options tend to be in risk-free assets [1].

Every investor often faces problems related to determining what kind of risky productive assets should be owned. Therefore, the role of risk management is needed to make investment decisions. Risk in investment is the uncertainty about the actual return on investment (actual return) smaller than the expected return on investment in the future. In the financial industry, risk measurement can be carried out in various ways. One of them is using the Value at Risk (VaR) method. The application of the Value at Risk (VaR) method is part of risk management. VaR is now widely accepted, used, and considered as the standard method of measuring risk. VaR can be defined as the estimated maximum loss that will be obtained during a certain time period under normal market conditions at a certain confidence level [3].

During the Covid-19 Pandemic, investor confidence in investing has decreased in companies whose shares have declined due to risk. PT. East Java Regional Development Bank Tbk or Bank Jatim is one of the BPDs whose shares are listed on the stock exchange or commonly called a public company where the company's shares are traded on the stock exchange. In the banking sector, the risk that occurs is bad credit, but on the other hand, Bank Jatim is one of the BPDs that received positive sentiment on July 3, 2020, namely news of placement of funds with BPD, and confirmed on July 27, 2020, with the official news of the placement of funds five BPD, one of which is Bank Jatim. With the existence of a positive catalyst during a pandemic, investor confidence has also increase and the funds placed can help the operations of the company.

Three main methods for calculating VaR are the parametric method (also called the variance-covariance method), the Monte Carlo simulation method, and the historical simulation method [4]. The three methods have characteristics with their respective advantages and disadvantages. The Monte Carlo simulation method assumes that returns are normally distributed in the simulation using the appropriate parameters and there is no assumption that portfolio returns are linear against a single asset return. VaR with historical simulation is a method that overrides the assumption of returns that are normally distributed or linear between portfolio returns and single asset returns, the VaR value is used to determine the estimated maximum loss that may occur so as to reduce this risk [4]. The variance-covariance method assumes that portfolio returns are linear to single asset returns and returns are normally distributed. This factor causes underestimation of the potential volatility of an asset or portfolio in the future.

This study uses the Monte Carlo simulation method to measure and analyze VaR on PT. East Java Regional Development Bank, Tbk which is listed on the IDX High Dividend 20 Index. This method is most often used to measure VaR because it can calculate various types of exposure (stocks) and risk arrangements. The aims of this research are to explain how the measurement of Value at Risk in PT. East Java Regional Development Bank Tbk with Monte Carlo simulation and to know the maximum potential loss in investment using Value at Risk (VaR) with the Monte Carlo simulation method on PT. Bank Pembangunan Daerah Jawa Timur Tbk.

\section{METHODS}

\subsection{Investment}

Investment is an investment made by a company into an asset with the hope of earning future income [5]. Investment is sacrificing assets that are owned now to get assets in the future with a larger amount [6]. Another opinion states that investment is a commitment to a number of funds or other resources that are carried out at this time, to obtain several benefits in the future [2] Investments can be made directly to the company or through intermediaries, and indirectly by buying other companies using the company.

Investment is a commitment to a number of funds or other resources carried out at this time, to obtain several benefits in the future. An investor buys a number of shares today in the hope of obtaining a profit from an increase in share prices or a number of dividends in the future, as a reward for the time and risk associated with the investment [1]. In investment decision making is a continuous process. The decision to invest can be made directly by individuals or by business entities that have excess funds. Investments can be made anywhere as long as they still generate returns that match the risk profile of investors, such as in the money market or the capital market or through equity crowdfunding to SMEs. Investments are usually divided into two parts: investment in paper assets and investment in real assets. 
Investments in paper assets such as in the money market, for example deposits, government securities, and others. For investment in tangible real assets in the purchase of productive assets, such as the establishment of boarding houses, apartments, company buildings and others.

\subsection{Stocks}

Stocks is a paper asset that is a sign of ownership of a person or entity in a company. Investors buying shares of a company are the owners of the company even though their ownership is very limited. This maybe only a fraction of a percentage because the number of shares issued by the company is usually up to millions. The form of shares is a sheet of paper which states that the owner of the paper is the owner of the company that issued the securities [7]. Shares (stocks) can be defined as a sign of the ownership or ownership of a person or entity in a company or limited liability company. Shares are in the form of a sheet of paper which states that the owner of the paper is the owner of the company that issued the securities [8].

The portion of share ownership is determined by how much capital is invested in the company. Stocks are the most popular capital market instrument. Conducting an Initial Public Offering (IPO), selling its shares to the public or the public, is one of the decisions a company wants to make funding for its company. Stocks are also the most popular investment and are in great demand by investors because stocks can provide attractive returns.

\subsection{Risk}

Risk is the amount of deviation between the expected return and the actual return [9]. The greater the deviation, the greater the level of risk accepted. Risk is the probability that it will occur naturally and have an adverse effect. Risk is often referred to as the deviation from the desired expectations with the outcome received. Two main components of risk, namely uncertainty (uncertainty) and exposure or size of assets [10]. Generally, the risk is divided into three, namely market risk, operational risk, and credit risk. Risk as the return variable against the desired return. In calculating risk, many use the standard deviation method which measures the deviation of the expected value in absolute terms from the value that has been received. Risk is not the weighted portfolio return of all security returns, portfolio risk is not the weighted average of all single risks. The main requirement to be able to reduce risk in a portfolio is that the return for each security is not positively and perfectly correlated [11]. The relationship between risk (risk) and rate of return (return), where the greater the risk borne by investors, the higher the desired rate of return before added value can be created and the higher the cost of capital that arises [12].

Systematic risk is known as market risk (physical market). The risk that cannot be eliminated is called systematic risk, while the risk that can be eliminated is called the risk that is not systematic [13]. Beta is an indicator of systematic risk. Beta is a measure of the volatility (volatility) return of a security or portfolio against market returns [11]. Stock beta can reflect conditions in the company, because the beta movement is determined by the company's daily stock price movements. The company's stock price reflects the company's financial condition in general and the psychological condition of market participants. The parameter used to measure systematic risk is beta, which is a tool to measure the volatility of a market risk, where volatility is the fluctuation in the return of a security within a certain period. If the risk is expressed as the extent to which the results obtained can deviate from the expected results, then the measure of the spread is the variance or standard deviation. The greater the value, the greater the deviation (meaning the risk is higher) [9].

If there are $n$ (many observations) of returns, then the expected return can be estimated by calculating the sample average (mean) return

$$
\mathbf{R}_{\mathbf{t}}=\frac{1}{2} \sum_{\mathbf{t}-1}^{\mathbf{n}} \mathbf{R}_{\mathbf{t}}
$$

The average return is then used to estimate the variance of each period, namely the square of the standard deviation per period

$$
\mathbf{S}^{2}=\frac{1}{\mathrm{n}-1} \sum_{\mathbf{t}-1}^{\mathrm{n}}(\overline{\mathbf{R t}}-\mathbf{R t})^{2}
$$

said the variance per period because the value depends on the time when the return is measured. The root of the variance (standard deviation) is the estimated risk of the stock price i.e.

$$
S=\sqrt{\frac{\sum_{\mathrm{t}-1}^{\mathrm{n}}(\overline{\mathbf{R t}}-\mathrm{Rt})^{2}}{\mathrm{n}-\mathbf{1}}}
$$

the annual standard deviation (annual volatility) can be estimated as follows

$$
\mathbf{S}=\sqrt{\mathbf{T} \frac{\sum_{\mathbf{t}-\mathbf{1}}^{\mathbf{n}}(\overline{\mathbf{R t}}-\mathbf{R t})^{2}}{\mathbf{n}-\mathbf{1}}}
$$

where:

St = annual standard deviation

$\mathrm{T}=$ number of trading days 


\subsection{Return}

The main reason people invest is to get profits [2]. Return is the benefit obtained from an investment, return itself has three important points, namely expected, actual, and risk returns. Expected return is the rate of return that investors expect in the future, actual return is the rate of return that investors have obtained. Both types of return still have their respective risks. Risk is the actual return that is obtained which is smaller than the expected minimum return. Return of an asset is the rate of return on assets or results obtained as a result of investing [14]. Return is one of the factors that motivates investors to invest because it can show a real price increase.

Return with time $\mathrm{t}$ is denoted by Rt return can be in the form of capital gains and dividends, but an asset, for example a stock that can only be held for one day or not a dividend, so that return is only the difference between the selling price and the buying price [10]. Investors are attracted by profits that tend to be large compared to the initial paid-up capital investment. Return measures the income because the return of an asset is the change in the initial price and return is one of the factors that motivates investors to invest [14]. Return is the result obtained from investment [15]. Returns can be in the form of actual returns that have occurred or expected returns that have not occurred but are expected to occur in the future. Realized return is calculated based on existing historical data, this is important because it is useful as a parameter in measuring company performance and is also useful as a basis for determining the expected return and risk that will be received in the future. The formula for calculating return is

$$
X_{t}=\frac{d_{t}-d_{t-1}}{d_{t-1}}
$$

where $\mathrm{Xt}$ is the stock price return on day $\mathrm{t}$, $\mathrm{dt}$ is the stock price on day $\mathrm{t}$, and $\mathrm{dt}-1$ is the stock price on day $\mathrm{t}$ 1.

\subsection{Value at Risk (VaR)}

Value at Risk (VaR) shows an estimate of the maximum possible loss on a stock portfolio due to market risk in a certain period and a certain level of confidence. VaR is the dominant methodology for estimating precisely how much money is at risk each day in financial markets [4]. If you discuss VaR, you will not be far from the term risk. Risk is a combination of the chance of an event with an impact that will occur, it can also be said to be pure risk and speculative risk. Pure risk is the possibility of something happening which if it happens will cause a loss, whereas speculation risk is also the possibility of something happening, but if it happens the result may be loss but it may also benefit [16]. The risk is defined as the likelihood of a loss, uncertainty, the spread of the actual results expected, and the chance that an outcome is different from the expected outcome [17]. Statistician defines risk as the degree of deviation of a value around a central position or around the mean point [18]. Risk is often associated with the possibility of unexpected or unexpected losses.

Therefore, to avoid unexpected risks, VaR calculations can be calculated, which can be calculated analytically, on a linear normal basis, Monte Carlo simulations, or historical simulations. $\mathrm{VaR}$ is formulated mathematically as the value of losses at a certain level of confidence $(1-\alpha)$ and it is the same as deriving the quantile of the probability distribution of the random variable, ie:

$$
\mathbf{P}\left(\mathbf{X}<\mathbf{x}_{\alpha}\right)=\alpha
$$

where $\mathrm{X} \alpha$ is $-\mathrm{VAR}$

If the distribution function $\mathrm{F}(\mathrm{x})$ of $\mathrm{X}$ is known, the corresponding quantile for any given $\alpha$ value can be calculated as

so that,

$$
\mathbf{x}_{\boldsymbol{\alpha}}=\mathbf{F}^{-1}(\boldsymbol{\alpha})
$$

$\operatorname{VaR}=-\mathbf{x}_{\mathbf{a}}=-\left(\mathbf{F}^{-1}(\boldsymbol{\alpha})\right)$

Value at Risk (VaR) is a tool used to measure market risk. Unlike volatility (standard deviation) which measures the size of the spread (the expression of data), $\mathrm{VaR}$ measures the amount of risk [10]. VaR can be interpreted as a loss that can be tolerated with a certain level of confidence. The approach that can be used in estimating the VaR value is divided into two, namely model building and historical simulation. In model building the VaR value is calculated as follows:

$$
\begin{gathered}
\mathrm{VaR}= \\
\text { exsposure x standard deviation } \mathrm{x} \text { confidence factor }
\end{gathered}
$$

Confidence factor is a quantile value $(z)$ of the normal distribution according to the selected confidence level [10]. In portfolios, VaR is defined as the estimated maximum loss that a portfolio will experience in a certain period under normal market conditions at a certain confidence interval [19]. An efficient portfolio is a portfolio that provides predetermined expected return. This portfolio can be determined by using a certain level of return expectations and minimizing a certain level of 
risk then maximizing the expected return expectations. A rational investor will choose this efficient portfolio because it is a portfolio formed by optimizing one of two dimensions, namely the expected return or portfolio risk [20].

The VaR value is generally accompanied by a probability indicating how likely the loss is not greater than the VaR value. VaR is a monetary loss value that will be experienced in a predetermined period. The following statement is a normal definition of $\mathrm{VaR}$ which is quoted from Best "Value at Risk is the maximum ammount of money that may be loss on a portfolio over a given time, with a given level of confidence." The following statement is a formal definition of VaR expressed by Jorion: "VaR summarizes the worse loss over a target horizon with a given level of confidence." In making it easier to understand the value of $\mathrm{VaR}$, Stambaugh states that VaR has the following functions: "1) Providing a common language for risk, 2) Allowing for more effective and consistent internal risk management, risk limit setting and evaluation, 3) Providing an enterprise-wide mechanism for external regulation, and 4) Providing investors with an understandable tool for risk assessment.". VaR has non-quantifiable limits, such as VaR only measures quantifiable risk, thus political risk, liquidity risk, employee risks are not calculated, and $\mathrm{VaR}$ also does not measure operational risk [21].

\subsection{Monte carlo application on the VaR}

Boyle in 1977 introduced the use of the Monte Carlo simulation method for risk measurement. To estimate the $\mathrm{VaR}$ value for a single portfolio or asset, the Monte Carlo simulation has several algorithms. The point is to do a simulation by generating random numbers based on the characteristics of the data to be generated, which is then used to estimate the VaR value [20].

This study uses secondary data obtained indirectly by studying documents related to research. These data include company profiles and stock price closing data obtained from the finance.yahoo.com website providing historical data on closing share prices. The data collection method used in this research is that the data obtained is relevant as a basis in the analysis process. The data collection technique is a documentation method by collecting, studying, and analyzing secondary data. The documentation method used in this study is to collect data on the closing share price of PT. Bank Pembangunan Daerah Jawa Timur Tbk. Companies that are the object of research are listed on the Indonesia Stock Exchange.

In this research, the object of research is the closing stock price data in the period October 2019 to Sep- tember 2020 on the stock price movements of PT. East Java Regional Development Bank Tbk (BJTM).

Collecting Data on Shares Price Closing was Carried out when daily closing price shares, namely data on closing prices recorded in the trading system each day. After the collection was carried out, the calculation of the normality test from the stock price return data to determine whether the data is normal distribution using SPSS software.

The Monte Carlo Simulation was carried out to generate random numbers, the random numbers then be used to estimate the $\mathrm{VaR}$ value. In generating random numbers, this study using Microsoft excel software to process stock price return data. After the monte carlo simulation was carried out to generate the random numbers, the results of the simulation are used to calculate the VaR value. Then, the average of several repetitions of VaR calculations was calculated to stabilize the Value at Risk (VaR) value.

\section{RESULTS AND DISCUSSION 3.1 Data return}

The first stage to find the data used for this research is the daily closing price of shares listed on the Indonesia Stock Exchange (IDX), namely PT. East Java Regional Development Bank Tbk (BJTM) for one trading year (245 trading days) from 1 October 2019 to 30 September 2020 [14]. The data was obtained from the home page finance.yahoo.com. Then the stock data is calculated the daily rate of return with the formula:

$$
R_{t}=\frac{P_{t}-P_{t-1}}{P_{t-1}}
$$

$$
\begin{array}{ll}
\text { Where: } & \\
\mathrm{Rt} & =\text { profit rate } \\
\mathrm{Pt} & =\text { the investment price at time } \mathrm{t} \\
\mathrm{Pt}-1 & =\text { investment price at time } \mathrm{t}-1
\end{array}
$$

In this study, stock dividends are ignored because they do not have a significant effect on the calculation. The rate of profit here is very important because it is the basis for calculating the portfolio Value at Risk (VaR).

The problem discussed in this study is to determine the amount of VaR calculation of PT. East Java Regional Development Bank Tbk (BJTM), so that investors can take actions or decisions for their portfolios in order to tolerate risks or losses that occur. In this study, the calculation of $\mathrm{VaR}$ on stocks uses the monte carlo simulation method with the help of Microsoft Excel and SPSS programs. 
Table 1. Value at risk calculation results.

\begin{tabular}{|l|c|c|c|}
\hline \multirow{2}{*}{ Stocks Code } & \multicolumn{3}{|c|}{ Value at Risk } \\
\cline { 2 - 4 } & $\alpha=1 \%$ & $\alpha=5 \%$ & $\alpha=10 \%$ \\
\hline BJTM & - Rp.5.871.809,812 & - Rp.4.183.103,967 & -Rp.3.195.086,406 \\
\hline
\end{tabular}

\subsection{Daily stock closing price}

The following is a chart of stock returns at PT. East Java Regional Development Bank Tbk. From Figure 1, this can be seen that the daily stock closing price movement from October 2019 to September 2020 tends to fluctuate, where the stock price return movement moves between -0.08 and 0.12 . The return chart of the daily stock closing price shows that the return on stocks is very volatile. It can be very high and very low to negative. From the data on the daily closing price of PT. East Java Regional Development Bank Tbk (BJTM) in the period 1 October 2019 to 30 September 2020, the share price ranges from Rp. 400.00 to Rp. 710.00 and the average share price is Rp. 585.38 and the total share price is Rp. Rp. 12,970,822.04.

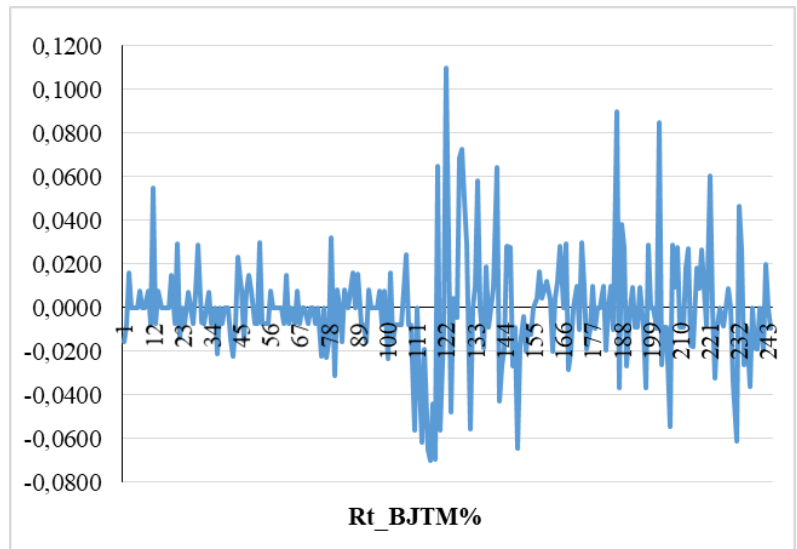

Figure 1. Graph of daily stock closing price return for the period October 2019 to September 2020 PT. Bank Pembangunan Daerah Jawa Timur Tbk.

\subsection{Value at Risk Calculation Results}

Table 1 shows that the results of VaR calculations using the monte carlo simulation method. This can be concluded that the higher the level of research confidence, the higher the VaR estimation results and vice versa. From the analysis of $\mathrm{VaR}$ calculations using the monte carlo simulation method, it can be seen that the VaR of BJTM shares at a $99 \%$ confidence level means that investors will experience investment losses of Rp. $5,871,809,812$, or $6 \%$, at the $95 \%$ confidence level, investors will experience a loss of Rp. 4,183,103,967, or $4 \%$, and at a confidence level of $90 \%$, investors will experience a loss of Rp. 3,195,086,406, or 3\% of the total initial funds invested.

$$
\begin{array}{cl}
\text { Stocks Code } & \text { Value at Risk } \\
\alpha=1 \% & \alpha=5 \% \quad \alpha=10 \% \\
\text { BJTM } & - \text { Rp.5.871.809,812 }
\end{array}
$$

Rp.4.183.103,967-Rp.3.195.086,406

\section{CONCLUSION}

There are two valuable conclusions in this study; firstly, This research shows how the application of Value at Risk ( $\mathrm{VaR}$ ) measurement on stocks cases trough monte carlo simulation method in single portofolio (BJTM share) of PT Bank Pembangunan Daerah Jawa Timur (BJTM) for the period October 2019 to September 2020. From the calculation of the average VaR value in the shares of PT Bank Pembangunan Daerah Jawa Timur (BJTM), the VaR value is -5871809.812 at the $99 \%$ confidence level, -4183103.967 at the $95 \%$ confidence level, and -3195086.406 at the level of confidence. $90 \%$ confidence (a negative sign indicates the loss) within one day.

According to this research, the maximum loss in a confidence level $99 \%$ will not exceed from IDR $5,871,809,812$, in a confidence level $95 \%$ will not exceed IDR 4,183,103,967 and will not exceed from IDR $3,195,086,406$, in a confidence level $90 \%$, in single period. The possibility of a loss are $6 \%$ in $99 \%$ confidence level, $4 \%$ in $95 \%$ confidence level, and $3 \%$ in $90 \%$ of the total initial investment fund in BJTM share.

Secondly, based on the results of VaR calculations using the monte carlo simulation method at a confidence level of $99 \%, 95 \%$, and $90 \%$, it can be concluded that the level of confidence is directly proportional to risk because the higher the level of confidence used, the higher the probability of the maximum loss experienced by investors, vice versa.

\section{REFFERENCES}

[1] Tandelilin E 2007 Analisis Investasi dan Manajemen Portofolio 1st edition. Yogyakarta: BPPE.

[2] Tandelilin E 2010 Analisis Investasi dan Manajemen Portofolio 1st edition. Yogyakarta: BPFE.

[3] Jorion P 2007 Value at Risk: The New Benchmark Managing Financial Risk. 3rd edition. New York: The Mc Graw-Hill Companies

[4] Butler C 1999 Mastering Value at Risk. New York: Prentice Hall. 
[5] Martono and Harjito A 2010 Manajemen Keuangan 8th edition. Yogyakarta: Ekonisia.

[6] Rakhimsyah, L., \& Gunawan, B. (2011). Pengaruh Keputusan Investasi, Keputusan Pendanaan, Kebijakan Dividen, dan Tingkat Suku Bunga terhadap Nilai Perusahaan. Jurnal Investasi. Vol 7. No. 1, 31-45.

[7] Supramono G 2014 Transaksi Bisnis Saham \& Penyelesaian Sengketa Melalui Pengadilan. Jakarta: Prenada Media.

[8] Darmadji T and Fakhruddin 2011 Pasar Modal Indonesia. Jakarta: Salemba Empat.

[9] Halim A 2005 Analisis Investasi. Second edition. Jakarta: Salemba Empat.

[10] Ghozali I 2007 Manajemen Risiko Perbankan, Pendekatan Kuantitatif Value at Risk (VaR). Sema-rang: Badan Penerbit Universitas Diponegoro.

[11] Hartono J 2014 Teori Portofolio dan Analisis Investasi 8th edition. Yogyakarta: BPFEYogyakarta.

[12] Utomo L 1999 Economic Value Added Sebagai Ukuran Keberhasilan Kinerja Manajemen Perusahaan. Jurnal Akuntansi dan Keungan Vol. 1, No. $1,28-42$.

[13] Hanafi M 2011 Manajemen Keuangan Internasional Yogyakarta: BPFE-Yogyakarta.

[14] Rupert D 2004 Statistic and Finance. New York: Springer.

[15] Jogiyanto 2000 Analisis dan Desain Sistem Informasi: Pendekatan Terstruktur Teori dan Praktis Ap-likasi Bisnis. Yogyakarta: Andi.

[16] Siahaan H 2009 Manajemen Risiko Pada Perusahaan dan Birokrasi Jakarta: PT. Elex Media Komputindo.

[17] Vaughan E and Elliot C 1978 Fundamentals of Risk and Insurance (2nd Ed). Santa Barbara: John Wiley \& Son, Inc.

[18] Suswinarno 2013 Mengantisipasi Risiko dalam Pengadaan Barang/Jasa Pemerintah. Jakarta: Visimedia.

[19] Jorinon 2002 Value at Risk: The New Benchmark for Managing Financial Risk. 2nd edition. New York: The McGraw-Hill Companies, Inc

[20] Hartono J 2014 Teori Portofolio dan Analisis Investasi 8th edition. Yogyakarta: BPFEYogyakarta.

[21] Sartono R and Andika, A 2006 VaR Portofolio Optimal: Perbandingan Antara Metode Markowitz dan Mean Absolute Deviation. Jurnal Siasat Bisnis, 37-50. 